\title{
Erratum to: The growth and increase of the number of journals focusing on Spine: a scientific blessing?
}

\author{
Max Aebi · Marek Szpalski
}

Published online: 23 April 2014

(c) Springer-Verlag Berlin Heidelberg 2014

Erratum to: Eur Spine J (2014) 23:491-492

DOI 10.1007/s00586-014-3254-6

An error has occurred in the original article. The following keywords were not included in the Editorial text:

Keywords Impact factor - Citation index - Eigenfactor · Online publishing $\cdot$ Spine journals

The online version of the original article can be found under doi:10.1007/s00586-014-3254-6.

M. Aebi $(\square)$

Orthopaedic Department, Hislanden Salem Hospital, 25,

3000 Bern, Switzerland

e-mail: max.aebi@memcenter.unibe.ch

M. Szpalski

Department of Orthopedics, Iris South Hospitals,

1180 Brussels, Belgium

e-mail:mszp@skynet.be 